DOI: $10.34220 /$ issn.2222-7962/2019.4/18

УДК 674:657.2

МЕЖДУНАРОДНАЯ ТОРГОВЛЯ В ЛЕСНОЙ ПРОМЫШЛЕННОСТИ

\author{
аспирант Н.Р. Пирцхалава-Карпова \\ аспирант А.А. Карпов
}
1 - ФГАОУ ВО «Северный (Арктический) федеральный университет имени М.В. Ломоносова», г. Архангельск, Российская Федерация

Россия - самая богатая страна с лесными ресурсами. На ее долю приходится 22 \% лесного покрова планеты, половина мировых запасов хвойной древесины. По прогнозам, к 2030 году потребность в деловой древесине увеличится примерно на 150 млн кубометров, и существует лишь один реальный источник - запасы России. Запасы ресурсов сегодня составляют более 83 млрд кубометров. Дляпредприятий Архангельской области основными рынками сбыта продукции деревообработки являются Китай, США, Италия, Испания, Нидерланды и Египет. Исходя из этого, в исследовании была сформирована логистическая система экспорта по трем вариантам транспортировки. Кроме того, исследования проводились на основе материалов UNCTAD, EUROSTAT и FAO, а также технико-экономических данных SEARATES. При выборе варианта логистической системы применялась интегрированная экономическая оценка затрат по компонентам: материальный поток, информационный поток, логистические посредники. В исследовании рассматривались шесть потенциальных маршрутов для доставки лесных грузов между портами Восточной Азии (Шанхай) и Европы (Роттердам). По результатам проведенных исследований можно сделать следующие выводы. В исследовании рассматривался вопрос транспортировки по Северному морском пути (HIAR). Транспортировка по данному маршруту возможна только в случае глобального потепления и ускорения отступления арктического морского льда. Потенциал экономии на расстоянии из Азии в Европу делает северный маршрут вероятной движущей силой перемен в сети транспортировки.

Ключевые слова: логистика, логистическая система, логистическая операция, международная логистика, лесопромышленный комплекс, экспорт

\title{
INTERNATIONAL TRADE IN FOREST INDUSTRY
}

\author{
Post-graduate student N.R. Pirtskhalava-Karpova \\ Post-graduate student A.A. Karpov
}

FSAEI HE "Northern (Arctic) Federal University named after M.V. Lomonosov", Arkhangelsk, Russian Federation

\begin{abstract}
Russia is the richest country with forest resources. It accounts for $22 \%$ of the world's forest cover and half of the world's coniferous wood reserves. According to forecasts, the demand for commercial wood will increase by about 150 million cubic meters by 2030. There is only one real source - Russia's reserves. Reserves today amount to more than 83 billion cubic meters. For enterprises of the Arkhangelsk region, the main markets for woodworking products are China, the USA, Italy, Spain, the Netherlands and Egypt. Based on this, the study has formed a logistic export system for three transportation options. In addition, studies have been carried out on the basis of UNCTAD, EUROSTAT and FAO materials, as well as SEARATES technical and economic data. When choosing a logistics system option, an integrated economic assessment of costs by components has been used: material flow, information flow, and logistics
\end{abstract}


intermediaries. The study has examined six potential routes for delivering timber between ports in East Asia (Shanghai) and Europe (Rotterdam). Based on the results of the research, the following conclusions can be drawn. The study has addressed the issue of transportation along the Northern Sea Route (HIAR). Transportation along this route is possible only in the event of global warming and accelerated retreat of the Arctic sea ice. The economic strength for distance savings from Asia to Europe makes the northern route a likely driver of change in transportation networks.

Keywords: logistics, logistics system, logistic operation, international logistics, timber industry, export

\section{Введение}

Транспортная система часто описывается как жизненная система современного общества. Маршруты составляют фундаментальную часть этой системы для пассажирских и грузовых перевозок. Ожидается, что грузовые перевозки увеличатся по всей Европе на 80 \% до 2050 года. Международные грузовые перевозки морским транспортом увеличатся в четыре раза до 2050 года [7]. Морской транспорт - неотъемлемая часть международной логистической сети и способствует развитию глобальной торговли. Промышленные и контейнерные перевозки являются наиболее распространенными. С 1960-х годов контейнеры были широко использованы. Поскольку контейнеризация продолжалась, последние два десятилетия видели тенденцию дальнейшей интернационализации торговли и производства. Объем контейнерных грузов в мире составляет 17120 миллионов футов эквивалентной единицы (TEU) в 2017 году (UNCTAD, 2018) [5, 6]. Судоходная линия Азия-Европа, которая перевозила 23 миллиона TEU контейнеров в 2017 году, является одним из самых загруженных контейнерных маршрутов в глобальной сети судоходства (UNCTAD, 2018) [5, 6]. Маршрут Суэцкого канала (SCR) является традиционным и наиболее важным морским маршрутом, связывающим Азиатские и европейские рынки. По статистике, около 42 млн TEU контейнерных грузов, что составляет $24,5 \%$ мирового груза, было перевезено через Суэцкий канал, тем не менее, проход Суэцкого канала уже страдает от роста объемов торговли (Hui Zhao, 2016) [2]. Объем транзитных грузов более чем вдвое с 2000 года с 368 миллионами тонн в 2000 году и 822 миллионов тонн в 2017 году (Hui Zhao, 2016). Наращивание трафика может повлиять на пропускную способность канала. Короткие морские перевозки
(SSS) могут быть определены как транспортировка грузов морем между портами, которые не задействованы в пересечении океана. Короткие морские перевозки в настоящее время составляют почти 40 \% всех грузов, перемещаемых в Европе, и объемы выросли за эти годы, в то время как доля рынка была стабильной (EUROSTAT) [7]. В 2017 году всего на короткие морские перевозки в ЕС приходилось почти 1,8 млрд тонн грузов и представляло 60 процентов морского транспорта (EUROSTAT, 2017). Оптовые перевозки - это распределение неупакованных или больших партий сырья и сыпучих грузов, лесных грузов, а также можно выделить сырую нефть,зерно, уголь и руду.

\section{Методы и материалы}

Исследования проводились на основе материалов UNCTAD, EUROSTAT и FAO, а также технико-экономических данных SEARATES. При выборе варианта логистической системы применялась интегрированная экономическая оценка затрат по компонентам: материальный поток, информационный поток, логистические посредники. Существует множество потенциальных маршрутов для доставки лесных грузов между портами Восточной Азии и Северо-Западной Европы. Существуют шесть таких маршрутов между Шанхаем и Роттердамом (см. рис. 1) [3]:

1. Маршрут, включающий области тяжелого льда (HIAR): маршрут через Северный морской путь, который имеет очень ограниченный навигационный сезон для судов низкого ледового класса.

2. Интермодальный маршрут, включающий области среднего льда (MIIR): мультимодальный маршрут, проходящий через китайскую внутреннюю железную дорогу - Транссибирскую магистраль в Красноярск вдоль р. Енисей, затем отправляется на север через внутренний водный путь реки Енисея до Дудинки, а затем через 


\section{Менеджмент. Экономика. Организация}

морские суда, транспортирующие до Роттердама. Этот маршрут имеет более длительный сезон без льда, по сравнению с вышеупомянутым, но ограничен навигационным периодом реки Енисей.

3. Интермодальный маршрут, включающий область легкого льда (LIIR): интермодальный маршрут, который идет через китайскую внутреннюю железную дорогу - ТрансМонгольскую железную дорогу - Транссибирскую магистраль - российскую внутреннюю железную дорогу в Санкт-Петербург вдоль Балтийского моря, а затем через морские суда, транспортирующие до Роттердама. Этот маршрут имеет очень короткий навигационный период.

4. Интермодальный маршрут (WIR): интермодальный маршрут, проходящий через
Второй евразийский сухопутный мост в Новороссийск вдоль Черного моря, а затем через морские суда, транспортирующие до Роттердама через Черное море и Средиземное море. Данный маршрут имеет круглогодичный навигационный период.

5. Морской маршрут (WAR): маршрут по традиционному морскому маршруту Азия-Европа.

6. Сухопутный маршрут (DR): железнодорожный маршрут, проходящий через китайскую внутреннюю железную дорогу - ТрансМонгольскую железную дорогу - Транссибирскую магистраль - Европейскую железную дорогу в Роттердам.

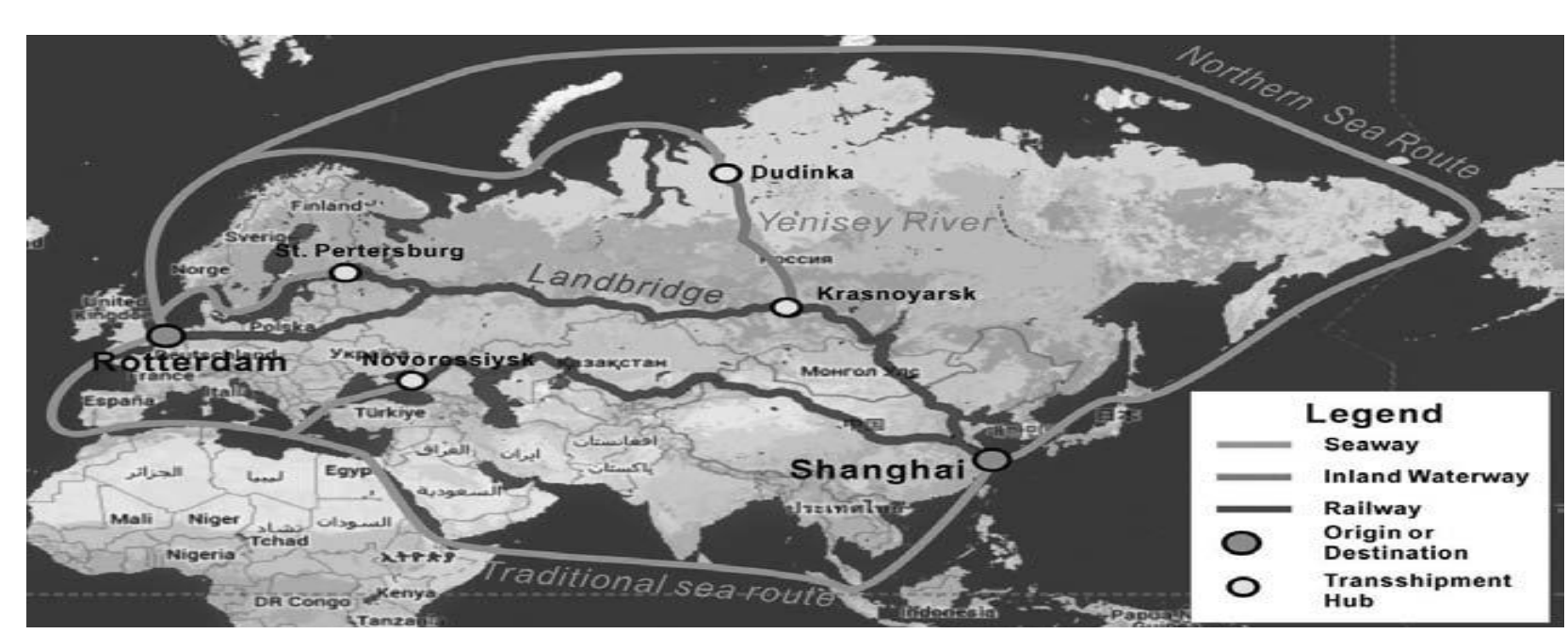

Рис. 1. Маршруты транспортировки между Шанхаем и Роттердамом [3] Korea Maritime Institute and East-West Center, 2013

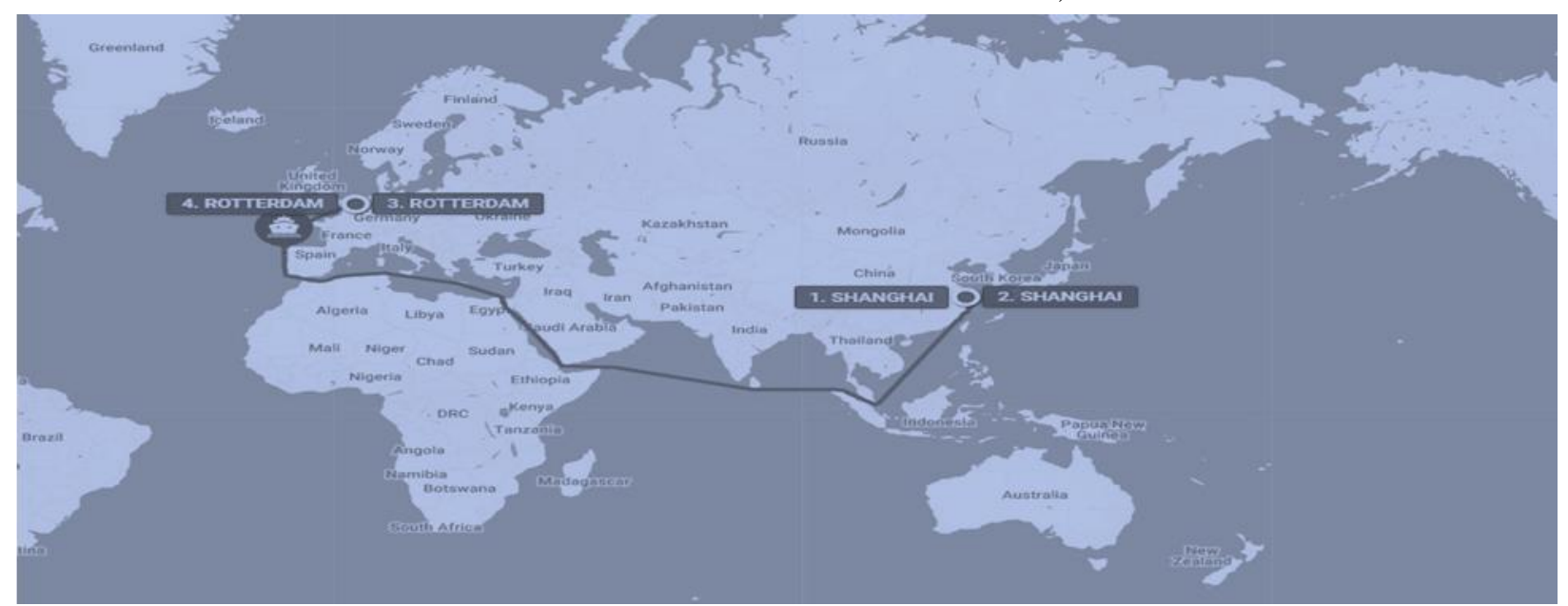

Рис. 2. Вариант транспортировки продукции по маршруту Шанхай - Роттердам Собственная разработка авторов, 2019 
Таблица 1

Классификация маршрутов

\begin{tabular}{|c|c|c|c|c|c|c|}
\hline $\begin{array}{c}\text { Наименование } \\
\text { маршрута }\end{array}$ & $\begin{array}{c}\text { Соотношение } \\
\text { расстояний } \\
\text { железной } \\
\text { дороги }\end{array}$ & $\begin{array}{c}\text { Соотношение } \\
\text { расстояний } \\
\text { внутренних } \\
\text { водных } \\
\text { артерий }\end{array}$ & $\begin{array}{l}\text { Соотношение } \\
\text { расстояний } \\
\text { морской } \\
\text { логистики }\end{array}$ & $\sum_{K_{M}}$ & $\begin{array}{c}\text { Время года и } \\
\text { продолжительность } \\
\text { навигации }\end{array}$ & $\begin{array}{c}\text { Пересечение } \\
\text { границы }\end{array}$ \\
\hline HIAR & & & $\begin{array}{l}\text { Шанхай- } \\
\text { СМП } \\
\text { Роттердам; } \\
14050 \text { км; } \\
100 \%\end{array}$ & 14,05 & $\begin{array}{c}\text { С конца августа до } \\
\text { начала октября; 1,33 } \\
\text { месяца }\end{array}$ & 0 \\
\hline MIIR & $\begin{array}{l}\text { Шанхай-Пекин- } \\
\text { Улан-Батор- } \\
\text { Красноярск; } \\
5250 \text { км; 42\% }\end{array}$ & $\begin{array}{c}\text { Красноярск- } \\
\text { Енисей - } \\
\text { Дудинка; } \\
2000 \text { км; 16\% }\end{array}$ & $\begin{array}{c}\text { Дудинка - } \\
\text { Роттердам; } \\
5150 \text { км; 42\% }\end{array}$ & 12,40 & $\begin{array}{c}\text { С середины июля. до } \\
\text { середины октября } \\
\text { (море), с июня по } \\
\text { сентябрь (река); 2,50 } \\
\text { месяца } \\
\end{array}$ & 2 \\
\hline LIIR & $\begin{array}{c}\text { Шанхай-Пекин- } \\
\text { Улан-Батор- } \\
\text { Пермь-Санкт- } \\
\text { Петербург; } \\
9600 \text { км; 80\% } \\
\end{array}$ & & $\begin{array}{c}\text { Санкт- } \\
\text { Петербург- } \\
\text { Роттердам; } \\
2400 \text { км; } 20 \%\end{array}$ & 12,00 & $\begin{array}{c}\text { С начала мая до } \\
\text { конца ноября; } 6,67 \\
\text { месяцев }\end{array}$ & 2 \\
\hline WIR & $\begin{array}{c}\text { Шанхай- } \\
\text { Урумчи- } \\
\text { Алматы- } \\
\text { Волгоград- } \\
\text { Новороссийск; } \\
9600 \text { км; 59\% }\end{array}$ & & $\begin{array}{l}\text { Новороссийс } \\
\text { к-Роттердам; } \\
6750 \text { км; } 41 \%\end{array}$ & 16,35 & $\begin{array}{c}\text { Круглогодично; } 12 \\
\text { месяцев }\end{array}$ & 2 \\
\hline WAR & & & $\begin{array}{c}\text { Шанхай- } \\
\text { Суэцкий } \\
\text { канал- } \\
\text { Роттердам; } \\
19300 \text { км; } \\
100 \%\end{array}$ & 19,30 & $\begin{array}{c}\text { Круглогодично; } 12 \\
\text { месяцев }\end{array}$ & 0 \\
\hline$\overline{\mathrm{DR}}$ & $\begin{array}{c}\text { Шанхай-Пекин- } \\
\text { Улан-Батор- } \\
\text { Москва- } \\
\text { Берлин- } \\
\text { Роттердам; } 11 \\
900 \text { км; } 100 \%\end{array}$ & & & 11,90 & $\begin{array}{c}\text { Круглогодично; } 12 \\
\text { месяцев }\end{array}$ & 6 \\
\hline
\end{tabular}

Собственная разработка авторов, 2019

Таблица 2

Крупнейшие страны-экспортеры лесной продукции (по данным FAO, 2018) [4]

\begin{tabular}{|c|c|}
\hline \multicolumn{2}{|r|}{ Процентная доля мирового экспорта } \\
\hline Деловой круглый лес & $\begin{array}{l}\text { Российская Федерация (15\%); Новая Зеландия (15\%); Соединенные Штаты Америки (10\%); Канада } \\
\text { (6\%); Чехия (5\%); Австралия (3\%); Франция (3\%); Германия (3\%); Норвегия (3\%); Папуа-Новая Гвинея } \\
(3 \%) \text {. }\end{array}$ \\
\hline Древесные пеллеты & $\begin{array}{l}\text { Соединенные Штаты Америки (26\%); Канада (11\%); Латвия (8\%); Вьетнам (8\%); Российская Федерация } \\
(7 \%) \text {; Эстония (6\%); Австрия (3\%); Малайзия (3\%). }\end{array}$ \\
\hline Пиломатериалы & $\begin{array}{l}\text { Канада (21\%); Российская Федерация (19\%); Швеция (9\%); Финляндия (6\%); Германия }(5 \%) \text {; } \\
\text { Соединенные Штаты Америки (5\%); Австрия (4\%); Таиланд (3\%). }\end{array}$ \\
\hline Шпон & $\begin{array}{l}\text { Вьетнам (15\%); Российская Федерация (14\%); Канада (14\%); Китай (7\%); Соединенные Штаты Америки } \\
(5 \%) \text {; Малайзия (4\%); Мьянма (4\%); Новая Зеландия (3\%); Габон (3\%). }\end{array}$ \\
\hline $\begin{array}{l}\text { Листовые } \\
\text { материалы }\end{array}$ & $\begin{array}{l}\text { Китай (16\%); Канада (9\%); Германия (7\%); Таиланд (6\%); Российская Федерация (6\%); Малайзия (4\%); } \\
\text { Бразилия (4\%); Польша (4\%); Беларусь (3\%); Индонезия (3\%); Австрия }(3 \%) ; \text { Франция (3\%); Бельгия } \\
(3 \%) ; \text { Румыния (3\%). }\end{array}$ \\
\hline Бумажная масса & $\begin{array}{l}\text { Бразилия (22\%); Канада (16\%); Соединенные Штаты Америки (12\%); Индонезия (7\%); Чили (7\%); } \\
\text { Финляндия (6\%); Швеция (5\%); Уругвай (4\%); Российская Федерация (4\%). }\end{array}$ \\
\hline $\begin{array}{l}\text { Рекуперированная } \\
\text { бумага }\end{array}$ & $\begin{array}{l}\text { Соединенные Штаты Америки (32\%); Соединенное Королевство (8\%); Япония (7\%); Франция (5\%); } \\
\text { Германия (5\%); Нидерланды (5\%); Канада (4\%); Италия (3\%); Бельгия }(3 \%) .\end{array}$ \\
\hline Бумага и картон & $\begin{array}{l}\text { Германия (12\%); Соединенные Штаты Америки (10\%); Швеция (9\%); Финляндия (8\%); Китай }(6 \%) ; \\
\text { Канада (6\%); Индонезия (4\%); Австрия (4\%); Франция (3\%); Бельгия }(3 \%) \text {; Италия (3\%); Республика } \\
\text { Корея (3\%); Российская Федерация (3\%). }\end{array}$ \\
\hline
\end{tabular}

The Food and Agriculture Organization (FAO), 2018 - www.fao.org 
Самый короткий из этих маршрутов - DR, a самый длинный - WAR (традиционный маршрут через Суэцкий канал). Хотя прежний маршрут намного короче, эффективность перевозок грузовых поездов намного ниже, чем у морских судов, и она проходит через страны с различными железнодорожными тарифами.

Общие расстояния MIIR и LIIR почти равны, но у первого есть более короткая железнодорожная ветка, поэтому его транспортная эффективность выше. Тем не менее, сезон без льда MIIR короче.

Продолжительность этих маршрутов будет сильно различаться из-за разных истоков или направлений. Например, если пункт назначения является портом в Восточном Средиземноморье, WIR, который транспортируется в Новороссийск, будет конкурентоспособным по сравнению с тремя верхними маршрутами, перечисленными в табл. 1. Более того, если происхождение будет выбрано среди корейских или японских, а не китайских портов, интермодальные маршруты, соединяющиеся с российским Дальневосточным портом Владивостока для перевалки и прохождения Транссибирской магистрали, могут быть выгодными вариантами (Xu Нua, 2013) [3]. В соответствии с этим соображением, учитывая происхождение (или пункт назначения), мы можем разграничить места назначения на разных маршрутах. Рыночной стоимостью маршрута является та, в которой маршрут минимизирует годовые общие затраты по сравнению с другими маршрутами. Основываясь на этом шаге, мы можем количественно сравнить каждый маршрут с объемом груза, созданным в его рыночной зоне.

\section{Результаты и обсуждение}

Россия - самая богатая страна с лесными ресурсами. На ее долю приходится 22 \% лесного покрова планеты, половина мировых запасов хвойной древесины. По прогнозам, к 2030 году потребность в деловой древесине увеличится примерно на 150 млн кубометров, и существует лишь один реальный источник - запасы России. Запасы ресурсов сегодня составляют более 83 млрд кубометров. Для сравнения, запасы деловой древесины США - около 23.5 млрд, Скандинавских стран - 3.7 млрд кубометров. Леса в России занимают $45.5 \%$ территории, и это превышает показатель Канады, Бразилии, США и Германии. В данном сравнении Россия уступает Японии, Финляндии, Анголе и Швеции (49 \%) (FAO, 2018) [4]. Одной из особенностей лесопромышленного комплекса России является то, что большинство лесозаготовительных и лесоперерабатывающих предприятий сильно удалено от потребителей. При такой огромной территории и слаборазвитой транспортной инфраструктуре это определяет большую значимость транспортных расходов в экономике предприятий и значительные потери материалов в лесной промышленности. В последнее время увеличивается удельный вес смешанных (мультимодальных, интермодальных) перевозок лесных грузов несколькими видами транспорта по единому перевозочному документу с передачей грузов в пунктах перевалки одним перевозчиком другому без участия грузовладельца. Пример: автомобильная доставка березовой клееной фанеры на железнодорожную станцию железнодорожный транспорт до порта - морская доставка судном в порт назначения - Роттердам.

Для предприятий Архангельской области основными рынками сбыта березовой клееной фанеры являются Китай, США, Германия, Великобритания, Италия, Нидерланды и Египет.

В качестве примера, пунктом отгрузки является Архангельский морской торговый порт (Arkhangelsk seaport), пунктом назначения Rotterdam International Trading Co. Объем перевозимой продукции составляет $7800 \mathrm{~m}^{3}$. Транспортировка фанеры осуществляется морским транспортом на судне типа «Иоганн Махмасталь», железнодорожным и автомобильным транспортом.

Выбранное в качестве транспортного средства судно Северного морского пароходства «Iohann Mahmastal» имеет арктический ледовый класс. Дальность плавания судна может обеспечить выполнение рейса Архангельск - Роттердам, огибая Финляндию, Швецию и Норвегию (3 500 морских миль). При такой киповой вместимости трюмов, равной 9450 м $^{3}$ и удельным погрузочным объемом для фанеры в пачках (справочные данные: 1,45 $\mathrm{m}^{3} / \mathrm{M}^{3}$ ), расчетная грузовая партия продукции составляет около $7800 \mathrm{~m}^{3}$. Кроме продукции деревообработки, 
размещаемой в трюмах, судно может принять другие грузы для транспортировки на палубе. Кроме того, возможна погрузка контейнеров на палубу. Это позволяет не только увеличить использование грузоподъемности судна, но и несколько снизить ставку фрахта. Карты транспортировки по маршруту «Архангельск Роттердам (Rotterdam International Trading Co.)» представлены на рис. 3-5.

Минимум суммарных затрат на осуществление логистической операции включает: а) доставку до места основной погрузки в основной транспорт; б) хранение запаса судовой партии; в) доставку к борту судна; г) в том числе упаковку; д) погрузку на борт судна; е) основную перевозку; ж) выгрузку в порту назначения.

Минимум суммарных затрат, руб., определяется по формуле

$$
C=C_{\text {д1 }}+C_{3}+C_{\text {д2 }}+C_{\text {у }}+C_{\text {п }}+C_{\text {оп }}+C_{\text {в }} \rightarrow \min ,
$$

где $C_{\text {д1 }}$ - доставка до места погрузки в основной транспорт; $C_{3}-$ хранение запаса судовой партии; $C_{\text {д2 }}-$ доставка к борту судна; $C_{\text {у }}$ - затраты на упаковку; $C_{\text {п }}-$ погрузка на борт судна; $C_{\text {оп }}-$ основная перевозка; $C_{\text {в }}-$ выгрузка в порту назначения.

Таблица 3

Крупнейшие страны-импортеры лесной продукции (по данным FAO, 2018) [4]

\begin{tabular}{|c|c|}
\hline \multicolumn{2}{|c|}{ Процентная доля мирового импорта } \\
\hline Деловой круглый лес & $\begin{array}{l}\text { Китай (43\%); Германия (7\%); Австрия (7\%); Швеция (6\%); Канада (5\%); Индия (4\%); Финляндия (4\%); } \\
\text { Республика Корея (3\%); Бельгия (3\%); Япония (3\%). }\end{array}$ \\
\hline Древесные пеллеты & Соединенное Королевство (36\%); Дания (16\%); Республика Корея (13\%); Италия (9\%); Бельгия (6\%). \\
\hline Пиломатериалы & $\begin{array}{l}\text { Китай }(26 \%) \text {; Соединенные Штаты Америки (18\%); Соединенное Королевство (5\%); Япония }(4 \%) \text {; } \\
\text { Германия (4\%); Италия (3\%); Египет (3\%). }\end{array}$ \\
\hline Шпон & $\begin{array}{l}\text { Китай (22\%); Япония (8\%); Соединенные Штаты Америки (8\%); Индия (8\%); Италия (4\%); Малайзия } \\
(4 \%) \text {; Испания (3\%); Вьетнам (3\%); Турция (3\%); Республика Корея (3\%); Германия }(3 \%) \text {; Франция } \\
(3 \%) \text {. }\end{array}$ \\
\hline $\begin{array}{l}\text { Листовые } \quad \text { древесные } \\
\text { материалы }\end{array}$ & $\begin{array}{l}\text { Соединенные Штаты Америки (17\%); Германия (7\%); Япония (5\%); Соединенное Королевство (4\%); } \\
\text { Канада (4\%); Польша (4\%); Китай (3\%); Италия (3\%); Республика Корея }(3 \%) \text {; Франция (3\%). }\end{array}$ \\
\hline Бумажная масса & $\begin{array}{l}\text { Китай (37\%); Соединенные Штаты Америки (9\%); Германия (7\%); Италия (6\%); Республика Корея (4\%); } \\
\text { Франция (3\%); Япония (3\%). }\end{array}$ \\
\hline Рекуперированная бумага & $\begin{array}{l}\text { Китай (46\%); Германия (8\%); Индия (6\%); Нидерланды (5\%); Индонезия (4\%); Испания (3\%); Таиланд } \\
(3 \%) \text {; Мексика (3\%); Республика Корея (3\%). }\end{array}$ \\
\hline Бумага и картон & $\begin{array}{l}\text { Германия (10\%); Соединенные Штаты Америки (8\%); Китай (5\%); Соединенное Королевство (5\%); } \\
\text { Италия (5\%); Франция (4\%); Польша (3\%); Мексика (3\%); Бельгия }(3 \%) \text {; Индия (3\%); Испания }(3 \%) ; \\
\text { Канада (3\%). }\end{array}$ \\
\hline
\end{tabular}

The Food and Agriculture Organization (FAO), 2018 - www.fao.org.

Таблица 4

Информация о портах [1]

\begin{tabular}{|c|c|c|c|c|c|c|}
\hline \multirow[t]{2}{*}{ Порт } & \multirow{2}{*}{$\begin{array}{c}\text { Расположение } \\
\text { (бассейн) }\end{array}$} & \multirow{2}{*}{$\begin{array}{c}\text { Габариты судов } \\
\text { (длина* } \\
\text { осадка), м }\end{array}$} & \multicolumn{2}{|c|}{ Причалы } & \multirow{2}{*}{$\begin{array}{c}\text { Грузооборот, } \\
\text { млн т }\end{array}$} & \multirow[t]{2}{*}{ Примечание } \\
\hline & & & Число & $\begin{array}{c}\text { Протяжен- } \\
\text { ность, м }\end{array}$ & & \\
\hline 1 & 2 & 3 & 4 & 5 & 6 & 7 \\
\hline $\begin{array}{l}\text { Arkhangelsk Sea Port } \\
\text { (Arkhangelsk) }\end{array}$ & $\begin{array}{c}\text { White Sea, } \\
\text { delta rivers } \\
\text { Northern Dvina }\end{array}$ & $180 * 9,2$ & 7 & 1162,4 & 4,2 & $\begin{array}{c}\text { Ice breaking } \\
\text { service } \\
\text { in winter }\end{array}$ \\
\hline Rotterdam & Northsea & - & 90 & 70000 & 250 & - \\
\hline
\end{tabular}

Пирцхалава Н.Р., 2018 


\section{Менеджмент. Экономика. Организация}

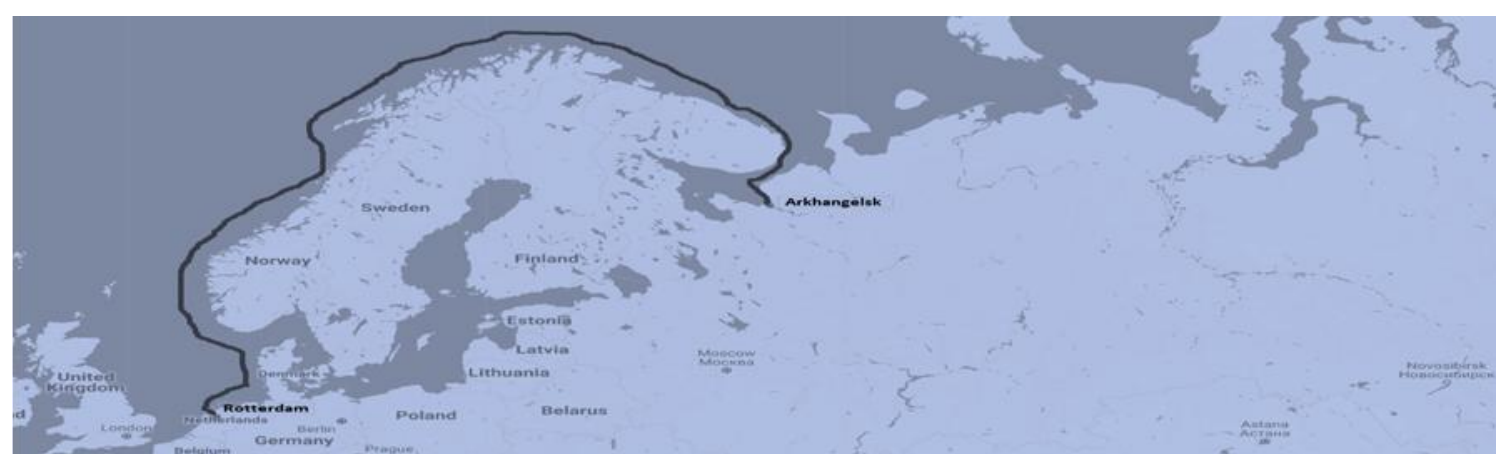

Рис. 3. Карта морской транспортировки по маршруту «Архангельск - Роттердам (Rotterdam International Trading Сo.)»; Собственная разработка авторов, 2019

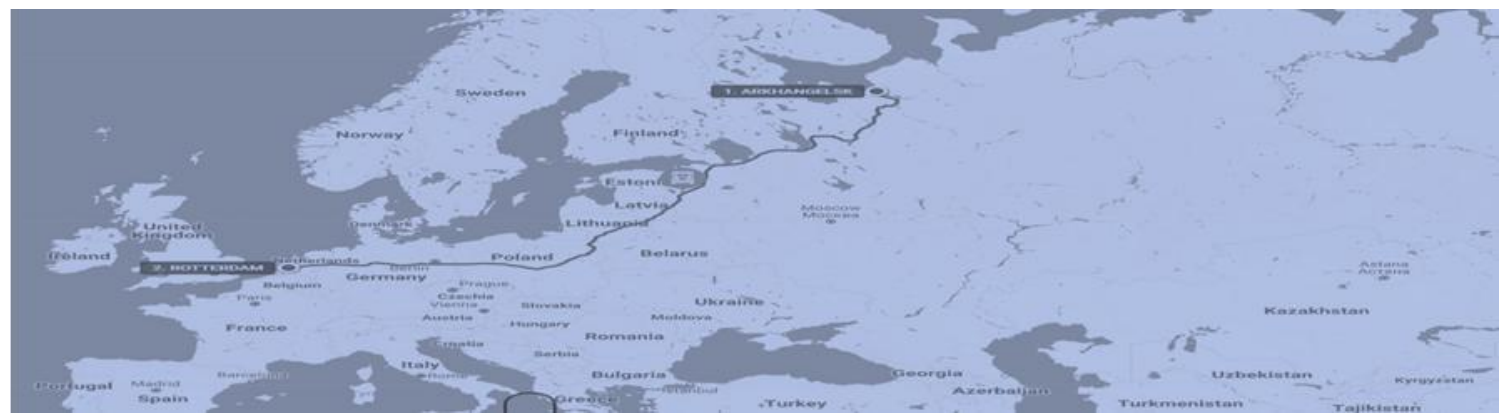

Рис. 4. Карта автомобильной транспортировки по маршруту «Архангельск - Роттердам (Rotterdam International Trading Co.)»; Собственная разработка авторов, 2019

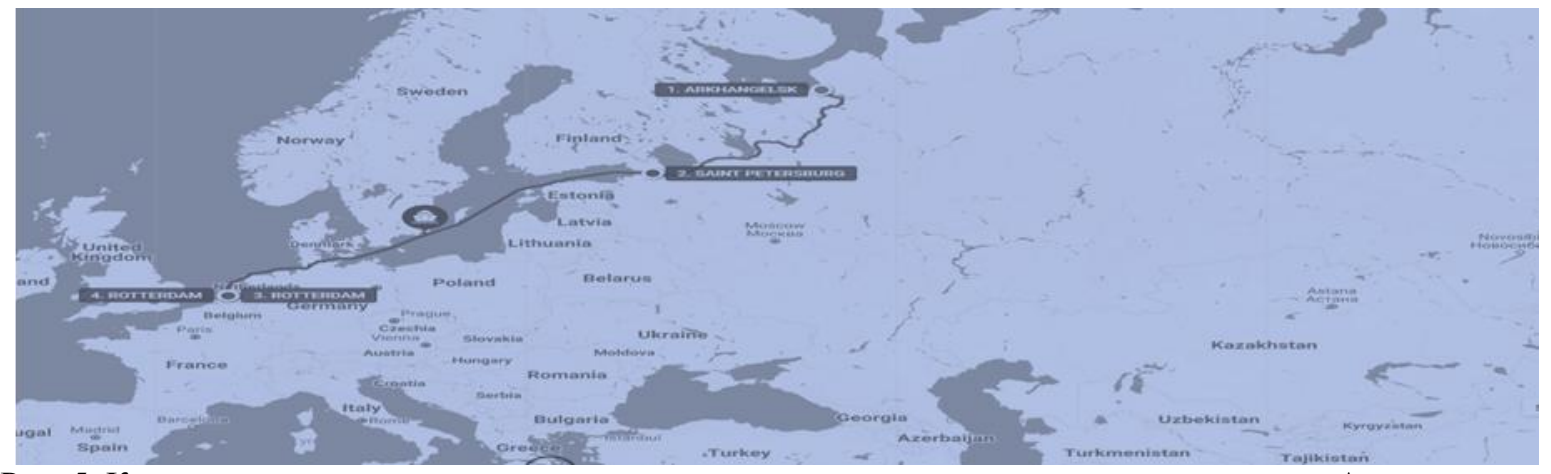

Рис. 5. Карта транспортировки железнодорожным и морским транспортом по маршруту «Архангельск Роттердам (Rotterdam International Trading Со.)»; Собственная разработка авторов, 2019

Таблица 5

Вариантный расчет логистических издержек

\begin{tabular}{|c|c|c|c|c|}
\hline \multirow{2}{*}{} & \multirow{2}{*}{ Indicator } & \multicolumn{2}{|c|}{ Options } \\
\cline { 3 - 5 } & & Sea transport & Automobile transport & $\begin{array}{c}\text { Railway transport + Sea } \\
\text { transport }\end{array}$ \\
\hline & 1 & 2 & 3 & 4 \\
\hline 1 & Distance, $\mathrm{km}$ & 4070 & 3200 & 3500 \\
\hline 2 & $\begin{array}{c}\text { Transportation rate, } \\
\text { rub./m }\end{array}$ & 1960 & 1238 & 1721 \\
\hline
\end{tabular}

Собственная разработка авторов, 2019

Логистические издержки складываются из стоимости транспортировки грузов на различных видах транспорта, которая определяется тарифом или фрахтовой ставкой. К основным факторам, влияющим на размер платы при транспортировке грузов по железной дороге, относятся: а) скорость перевозки; б) вид отправки (повагонная, контейнерная, малотоннажная, мелкая); в) расстояние 
перевозки; г) тип вагона, в котором осуществляется перевозка (универсальные вагоны, изотермические, специализированные, цистерны, платформы); д) принадлежность вагона или контейнера (кто является собственником); е) количество перевозимого груза [12].

В табл. 5-6 приведен вариантный расчет логиистических издержек транспортировки морским, автомобильным и железнодорожным транспортом.

Логистическая система (Logistic system) сложная организационно структурированная экономическая система, состоящая из элементов звеньев логистической системы, взаимосвязанных в едином процессе управления материальными, информационными и финансовыми потоками. Пример логистической системы для березовой клееной фанеры приведен в таблице. Целью логистической системы является доставка продукции в заданное место, в нужном количестве и ассортименте в максимально возможной степени подготовленных к производственному или личному потреблению при заданном уровне издержек [10,
11]. Фанерная продукция относится к наиболее эффективным видам древесных материалов, благодаря большому диапазону форматов и высоким значениям физико-механических свойств, а также, возможности прогнозирования требуемых свойств за счет изменения структуры сборки пакетов и технологии производства. Кроме того, продукция способна заменять пиломатериалы во многих конструкциях и сферах применения. Фанеру изготавливают путем прессования листов шпона толщиной 1-2 мм и более с перекрестным направлением волокон в смежных слоях. При данной конструкции происходит увеличение прочности материала (выше прочности исходной древесины) и снижение негативного влияния пороков и анизотропии. Для предприятий Архангельской области основными рынками сбыта продукции деревообработки являются Китай, США, Великобритания и Европейский рынок $[8,9]$. Исходя из этого, была сформирована логистическая система экспорта по трем вариантам транспортировки.

Таблица 6

Подробный расчет логистических издержек

\begin{tabular}{|c|c|c|c|c|}
\hline \multirow{2}{*}{\multicolumn{2}{|c|}{ Supply Chain Parameter, Cost Element }} & \multicolumn{3}{|c|}{ Logistics chain - options for routes } \\
\hline & & $\begin{array}{l}\text { Arkhangelsk } \\
\text { Rotterdam }\end{array}$ & $\begin{array}{c}\text { Arkhangelsk } \\
\text { S.Petersburg } \\
\text { Rotterdam } \\
\end{array}$ & $\begin{array}{c}\text { Arkhangelsk } \\
\text { Rotterdam }\end{array}$ \\
\hline \multicolumn{2}{|l|}{ ShippingName } & \multicolumn{3}{|c|}{ Plywood } \\
\hline \multicolumn{2}{|l|}{ Cargoparty, $\mathrm{m}^{3}$} & 6900 & 6900 & 6900 \\
\hline \multirow{2}{*}{\multicolumn{2}{|c|}{$\begin{array}{l}\text { Loading at the point of departure } \\
\text { Container delivery, port delivery, } \\
\text { shipboarding }\end{array}$}} & 2,00 & 3,00 & 3,00 \\
\hline & & 4,00 & 4,00 & 0,00 \\
\hline \multicolumn{2}{|l|}{ Porttransshipment } & 0,00 & 7,00 & 0,00 \\
\hline \multirow{2}{*}{\multicolumn{2}{|c|}{$\begin{array}{l}\text { Freight - seavessel } \\
\text { Railway fare including } \\
\text { car levy }\end{array}$}} & 18,00 & 0,00 & 0,00 \\
\hline & & 0,00 & 0,60 & 0,00 \\
\hline Carfare & 20 & 0,00 & 0,00 & 18,00 \\
\hline SalesAgentServices & $1,50 \%$ & 1,13 & 1,13 & 1,13 \\
\hline Freightagentservices & $0,50 \%$ & 0,11 & 0,02 & 0,09 \\
\hline Expertise & $0,30 \%$ & 0,225 & 0,225 & 0,225 \\
\hline $\begin{array}{l}\text { Loss or damage insurance } \\
\text { goods in transit }\end{array}$ & $0,90 \%$ & 0,68 & 0,54 & 0,50 \\
\hline \multicolumn{2}{|l|}{ Total USD / unit of cargo } & 26,14 & 16,51 & 22,94 \\
\hline Estimated exchange rate USD / rub. & 75,00 & & & \\
\hline \multicolumn{5}{|l|}{ Thesame, Euro / rub. } \\
\hline \multicolumn{2}{|l|}{ Transportationdistance, $\mathrm{km}$} & 4070 & 3200 & 3500 \\
\hline \multicolumn{2}{|l|}{ Total rub. / unit of cargo } & 1960 & 1238 & 1721 \\
\hline
\end{tabular}

Собственная разработка авторов, 2019 
Таблица 7

Логистическая система автомобильной перевозки

\begin{tabular}{|c|c|c|c|}
\hline \multicolumn{4}{|c|}{ Архангельская область - Роттердам } \\
\hline \multirow{2}{*}{ Элементы логистической системы } & \multicolumn{3}{|r|}{ Компоненты логистической системы } \\
\hline & ЛК & ЛП & Логистическая операция \\
\hline Производитель & $*$ & & Arkhangelskplywoodfactory \\
\hline Склад производителя & $*$ & & Arkhangelskplywoodfactory \\
\hline Экспертиза качества & & * & ООО «Северная Экспертиза» \\
\hline Уполномоченный банк & & $*$ & ОАО «Сбербанк» \\
\hline Страховая компания & & $*$ & ООО «Росгосстрах» \\
\hline Экспортер - продавец & $*$ & & Arkhangelskplywoodfactory \\
\hline Склад экспортера & $*$ & & Arkhangelskplywoodfactory \\
\hline Агент & & * & DLH, Rotterdam \\
\hline Потенциальный покупатель & & $*$ & Rotterdam International Trading Co. \\
\hline Таможенный брокер - декларант & & $*$ & $\begin{array}{l}\text { Arkhangelskplywoodfactory } \\
\text { ЗАО «АФЗ»- постоянный экспортер }\end{array}$ \\
\hline Таможня в стране отгрузки & & * & Архангельская таможня \\
\hline Таможенный склад временного хранения & * & & Arkhangelskplywoodfactory \\
\hline Пунктотгрузки & $*$ & & $\begin{array}{l}\text { Архангельск - Архангельский морской торговый порт, } \\
\text { терминал «Экономия» }\end{array}$ \\
\hline Фитосанитарный контроль & & $*$ & Росприроднадзор - Архангельск \\
\hline Международный перевозчик & $*$ & & ОАО «Северное морское пароходство» \\
\hline Пунктназначения & $*$ & & Rotterdam, berth 76 \\
\hline Таможня в стране назначения & & $*$ & Rotterdam \\
\hline Фитосанитарный контроль & & $*$ & Санитарная инспекция в Нидерландах \\
\hline Импортер - покупатель & $*$ & & Rotterdam International Trading Co. \\
\hline Склад импортера & $*$ & & Rotterdam International Trading Co. \\
\hline Экспертиза качества & & $*$ & Инспекция качества в Нидерландах \\
\hline Страховая компания & & $*$ & Страховая компания Роттердам \\
\hline Банк (банки) & & $*$ & Netherlands Bank \\
\hline Конечный потребитель & $*$ & & Rotterdam International Trading Co. \\
\hline
\end{tabular}

Собственная разработка авторов, 2019

\section{Заключение}

По результатам проведенных исследований можно сделать следующие выводы. В исследовании вассматривался вопрос транспортировки по Северному морском пути (HIAR). Транспортировка по данному маршруту возможна только в случае глобального потепления и ускорения отступления арктического морского 
льда. Потенциал экономии на расстоянии из Азии в Европу делает СМП вероятной движущей силой перемен в сети транспортировки. Но даже при огромной проходимости через Суэцкий канал, он считается лучшим логистическим и незаменимым выбором [7, 13]. Результаты этого исследования очень полезны для оценки логистического потенциала как со стратегической, так и с тактической точек зрения. Дальнейшие исследования могут сосредоточиться на анализе гибких рынков лесных грузов с участием более потенциальных портов. При расчете логистической системы экспорта березовой клееной фанеры по маршруту Архангельск - Роттердам, можно сделать вывод, что наиболее рациональным маршрутом можно считать транспортировку автомобильным транспортом. Доля логистических издержек в ВВП на современном этапе развития мировой экономики достигает $20 \%$. Удельный вес расходов по хранению, транспортировке, упаковке, учету и другим операциям, обеспечивающим продвижение потребительских товаров от производителя до розничного покупателя, может превышать 70 \% от конечной цены продукта. Примерная структура этих издержек (в процентах): содержание запасов 45; складирование - 15; перевозки - 30, в том числе: магистральные - 20, технологические - 10 ; маркетинг - 10 .

\section{Библиографический список}

1. Пирцхалава, Н. Р. Национальная транспортная коммуникация в Арктике / Н. Р. Пирцхалава, А. А. Карпов, М. В. Дербин // Лесотехнический журнал. - 2018. - № 2 (30). - С. 185-195.

2. Hui Zhao. Study on China-EU container shipping network in the context of Northern Sea Route // Hui Zhao, Hao Hu, Yisong Lin // Journal of Transport Geography. - 2016. - No. (53). - P. 50-60.

3. Xu Hua. Comments on Chapter 2: Chinese perspective / Xu Hua // The Arctic in World Affairs: A North Pacific Dialogue on Arctic Marine Issues- Seoul and Honolulu: Korea Maritime Institute and East-West Center, 2013. P. 94-102.

4. The Food and Agriculture Organization (FAO) is a specialized agency of the United Nations. Forest products statistics, 2018, Accessed by 19 January 2019.

5. United Nations Conference on Trade and Development (UNCTAD). Key Statistics and Trends in Trade Policy, 2018, 1. -35 p.

6. United Nations Conference on Trade and Development (UNCTAD). Key Statistics and Trends in Trade Policy, 2017, 1. $-42 \mathrm{p}$.

7. United Nations Conference on Trade and Development, 2015. Review of Maritime Transport. United Nations. URL: http://unctad.org/en/PublicationsLibrary/rmt2015_en.pdf (Accessed by 8 May 2016).

8. Commercial Arctic shipping through the northeast passage: routes, resources, governance, technology, and infrastructure / A. B. Farré, S. R. Stephenson, L. Chen [et al.] // Polit. Geogr. - 2014. - No. 37. - P. $298-324$.

9. Lee Sung-Woo. Potential Arctic Shipping: Change, Benefit, Risk and Cooperation // The Arctic in World Affairs: A North Pacific Dialogue on Arctic Marine Issues. - Seoul and Honolulu: Korea Maritime Institute and EastWest Center, 2012. - P. 39-61.

10. Mitrova, T. Russian Perspectives / T. Mitrova // The Arctic in World Affairs: A North Pacific Dialogue on Arctic Marine Issues. - Seoul and Honolulu: Korea Maritime Institute and East-West Center, 2017. - P. 126-140.

11. International emission regulation in sea transport: Economic feasibility and impact / C. Sys, T. Vanelslander, M. Adriaenssens, I. Van Rillaer // Transportation Research. Part D (45), 2016. - P. 139-151.

12. Engström, R. The roads' role in the freight transport system / R. Engström // Transportation Research Procedia (14): 6th Transport Research Arena, 2016. - P. 1443-1452 p.

13. Gunnarsson, B. The Future of Arctic Marine Operations and Shipping Logistics / B. Gunnarsson // The Arctic in World Affairs: A North Pacific Dialogue on Arctic Marine Issues. - Seoul and Honolulu: Korea Maritime Institute and East-West Center, 2013. P. 37-62. 


\section{References}

1. Pirtskhalava N.R. (2018) Nacional'naja transportnaja kommunikacija v Arktike [National Transport Communication in the Arctic]. Nauchnyj lesotehnicheskij zhurnal [Scientific forestry journal], vol. 2, pp. 185-195 (In Russian).

2. Hui Zhao, Hao Hu, Yisong Lin. Study on China-EU container shipping network in the context of Northern Sea Route. Journal of Transport Geography (53), 2016, p. 50-60.

3. Xu Hua. Comments on Chapter 2: Chinese perspective. The Arctic in World Affairs: A North Pacific Dialogue on Arctic Marine Issues. Seoul and Honolulu: Korea Maritime Institute and East-West Center, 2013, p. 94-102.

4. The Food and Agriculture Organization (FAO) is a specialized agency of the United Nations. Forest products statistics, 2018, Accessed by 19 January 2019.

5. United Nations Conference on Trade and Development (UNCTAD). Key Statistics and Trends in Trade Policy, 2018, 1, $35 \mathrm{p}$.

6. United Nations Conference on Trade and Development (UNCTAD). Key Statistics and Trends in Trade Policy, 2017, 1, 42 p.

7. United Nations Conference on Trade and Development, 2015. Review of Maritime Transport. United Nations. URL: http://unctad.org/en/PublicationsLibrary/rmt2015_en.pdf.

8. Farré A.B., Stephenson S.R., Chen L. et al. (2014) Commercial Arctic shipping through the northeast passage: routes, resources, governance, technology, and infrastructure. Polit. Geogr. 37, pp. 298-324.

9. Lee Sung-Woo. Potential Arctic Shipping: Change, Benefit, Risk and Cooperation. The Arctic in World Affairs: A North Pacific Dialogue on Arctic Marine Issues. Seoul and Honolulu: Korea Maritime Institute and EastWest Center, 2012, p. 39-61.

10. Mitrova T. Russian Perspectives. The Arctic in World Affairs: A North Pacific Dialogue on Arctic Marine Issues. Seoul and Honolulu: Korea Maritime Institute and East-West Center, 2017, p. 126-140.

11. Sys C., Vanelslander T., Adriaenssens M., Van Rillaer I. (2016) International emission regulation in sea transport: Economic feasibility and impact. Transportation Research Part D (45), p. 139-151.

12. Engström R. (2016) The roads' role in the freight transport system. Transportation Research Procedia (14): 6th Transport Research Arena, 2016, p. 1443-1452.

13. Gunnarsson B. The Future of Arctic Marine Operations and Shipping Logistics. The Arctic in World Affairs: A North Pacific Dialogue on Arctic Marine Issues. Seoul and Honolulu: Korea Maritime Institute and East-West Center, 2013, p. 37-62.

\section{Сведения об авторах}

Пирихалава-Карпова Нана Роландиевна - аспирант очной формы обучения, высшая инженерная школа, кафедра лесопромышленных производств и обработки материалов ФГАОУ ВО «Северный (Арктический) Федеральный университет имени М.В. Ломоносова», г. Архангельск, Российская Федерация; е-таil: pirchalava.nr@edu.narfu.ru.

Карпов Александр Анатольевич - аспирант очной формы обучения, высшая школа естественных наук и технологий ФГАОУ ВО «Северный (Арктический) Федеральный университет имени М.В. Ломоносова», г. Архангельск, Российская Федерация; e-mail: lesnoy.monitoring @ gmail.com.

\section{Information about authors}

Pirtskhalava-Karpova Nana Rolandievna - PhD student, higher engineering school, Department of Forestry Production and Materials Processing, FSAEI HE "Northern (Arctic) Federal University named after M.V. Lomonosov", Arkhangelsk, Russian Federation; e-mail: pirchalava.nr@edu.narfu.ru.

Kavpov Alexandr Anatolievich - PhD student, higher school of science and technology, FSAEI HE "Northern (Arctic) Federal University named after M.V. Lomonosov", Arkhangelsk, Russian Federation; e-mail: lesnoy.monitoring@gmail.com. 